\title{
Sediment Fasies of Upper Part of Late Miocene Halang Formation in Kali Tajum, Gumelar Area, Banyumas - Central Java, Indonesia
}

\author{
Yan Rizal $^{1}$, Ricky Andrian Tampubolon ${ }^{1}$, Wahyu Dwijo Santoso ${ }^{1} \&$ Alfend Rudyawan ${ }^{1}$ \\ ${ }^{1}$ Geological Study Program of Institut Teknologi Bandung Jalan Genesha 10 Bandung 40132, Indonesia \\ Correspondence: Yan Rizal, Geological Department of Bandung Institute of Technology, Bandung- Indonesia. \\ E-mail: yan@gl.itb.ac.id
}

Received: June 26, 2019

doi:10.5539/mas.v13n8p22
Accepted: July 22, 2019

Online Published: July 25, 2019

\begin{abstract}
A detailed stratigraphy description and measurements of the sedimentary facies within the Halang Formation has been carried out to provide a thorough assessment of the architectural facies and depositional environment. The study area is located along the Tajum River in the District of Gumelar, Banyumas, Central Java-Indonesia where most of the Halang Formation is preserved in a good condition. Three cycles of facies association from basin plain, in channel to channel overbank deposits were able to be determined from the formation which indicate very active changes of sub-depositional environment that related to transgressive response influenced by the local tectonic during sedimentation takes place.
\end{abstract}

Keywords: Halang formation, Turbidite, lithofacies, Kali Tajum

\section{Introduction}

The stratigraphy of the study area follows the stratigraphy of the Majenang area (Kastowo \& Suwarna, 1996). The area is underlain by the deep marine to transitional sediments which belong to Halang Formation, Kumbang Formation and Tapak Formation. Mulhadiyono (2006) stated that within the deep-sea sediments, particularly the Halang Formation, there are traces of hydrocarbon that probably came out via fractures in sandstones (Tobing, 2002). Fanani (2012) suggested that based on the analysis of TOC content of the mudstone, by pyrolysis analysis and vitrinite reflectance analysis and the type of kerogen, the mudstone of Halang Formation have the ability to produce hydrocarbons by primary products such as gas (kerogen type III).

The Halang Formation is a turbidite deposit formed in the fore arc basin (Ardenta et al. 2016) at the time of the Miocene. This formation has a wide spread in Java, especially in Central Java (Praptisih and Kamtono, 2011; Ardenta, et Al, 2016; Rizal, et Al, 2016; Rizal et Al, 2017) and some in West Java (Abdurrokhim, et al, 2017). Identification of the body shape of the deep marine deposits in turbidite facies is very important especially with regard to the determination of the geometry of a reservoir. The problem that arises is the geometry of deep marine deposits in these turbidite facies is very complex and varied, and its existence depends on how, when, and the type of depositional environment (Slatt, 2003).

The paper aims to study the individual facies and the vertical architectural facies association of the Halang Formation that could unravel the change of their sub-depositional environment and its relationship with the presence of hydrocarbons. Tajum River in the Gumelar District of Central Java is selected as a study area because the river preserves outstanding and continuous sequence of the Halang Formation of which a detailed stratigraphic measurements can be carried out.

\subsection{Study Area}

Administratively research locations are in the Tajum river in Gumelar subdistrict, Banyumas, Central Java Province (Figure 1). 


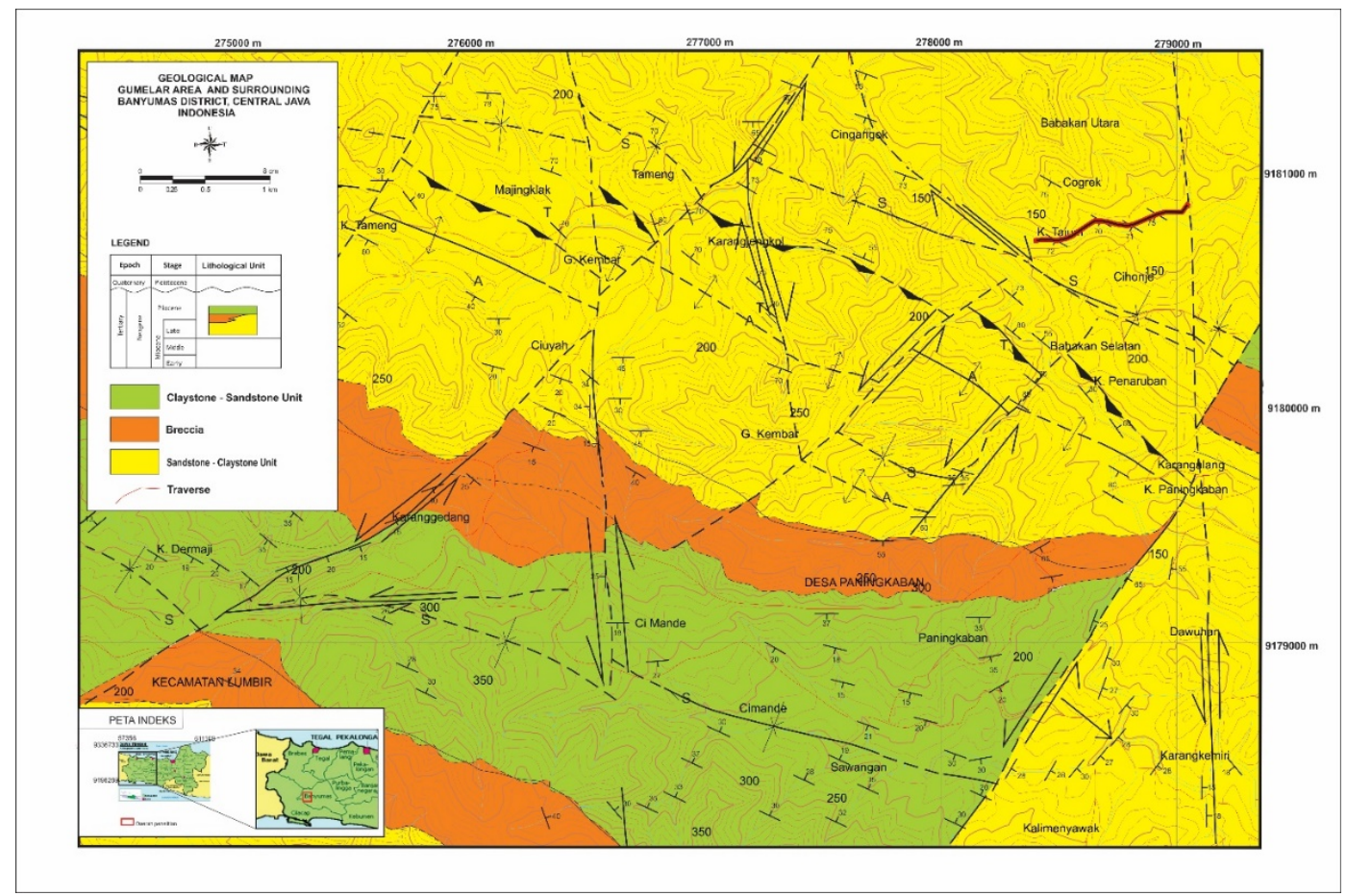

Figure 1. Geological Map of Studi Area and Traverse line (Modified from Tampubolon, 2014)

\subsection{Regional Setting}

According to physiographic map of Central Java (van Bemmelen, 1949), the study area belongs to South Serayu Mountains Zone. The Study area composed of steep hills, which extended to the northwest-southeast prolongation direction of South Serayu Mountains. Kastowo and Suwarna (1996) grouped a rocks forming of Majenang region in 7 Formation. Tampubolon (2014) looking at more restricted region mentioned only three rock Formation (Halang Formation, Kumbang Formation and Tapak Formation) exposed in the study area.

\subsection{Lithofacies}

Based on a lithology and it vertical succession character as well as sedimentary structures and the fossil content, the Halang Formation which exposed in the study area, interpreted as a turbidite deposit in the deep sea fan. This study takes a more detailed approach to determine the facies adjusted to turbidite system to improve the interpretation of the depositional environments and determine vertical succession that occurred in the study area.

\subsection{Deep Marine Turbidite Facies}

Gressly (1838) in Reading (2001) stated that facies are part of the rocks body that can be distinguished from the other rocks which formed in the specific conditions of sedimentation, which indicates the specific depositional environment. Certain facies should be distinguished from the rocks that laid above and below it, even laterally. Facies are then grouped into facies associations or can be divided into sub-facies.

According to Shanmugam (2006), knowledge of deep marine turbidite still in a state of "crisis" because the data is a result of drilling and seismic sea fan in the modern is still very rare, so that the dimensions of deep marine fans and sedimentation processes are debatable. The Interpretations of this deep marine turbidite in general refers to the ancient deep marine fan. According to Shanmugam (1985), facies should be applied both on the ancient and the modern deep marine fan.

Shanmugam (1985) maintain that the facies associations of deep marine turbidite deposition can be used to interpret the process of deposition of deep marine fan by assuming the following points

- Each sub-depositional environment has the characteristics of an association of a specific deposition process,

- Sedimentation process happens constantly all the time in the sub-deposition environment,

- All deep marine fan have identical facies development in each specific sub depositional environment

Mutti and Ricci Lucchi (1972) developed a model of the ancient deep marine fan facies (Figure 5). This facies models are then modified again by Stow (1985) and Pickering et al (1986). One of the modifications is used is 
classification modifications made by Stow (1985). This classification divides facies into 7 classes, 15 groups and 59 individuals facies. 7 classes divided by grain size, internal arrangement, and composition.

Table 1 shows the grainsize distribution for each class in order to maintain the consistency of the classification. Seven classes were able to be determined from various facies association within the formation.

Table 1. Grainsize distribution of each facies (Stow, 1985)

\begin{tabular}{|c|c|c|c|c|c|c|}
\hline \multirow{2}{*}{ Class } & \multicolumn{5}{|c|}{ Grain size } & \multirow{2}{*}{ Lithology } \\
\hline & Gravel & Sand & Silt & Mud & Clay & \\
\hline A & $>5 \%$ & & & & & Conglomerates and conglomeratic sandstones \\
\hline B & $<5 \%$ & $>80 \%$ & & & & Sandstones \\
\hline $\mathrm{C}$ & & $20-80 \%$ & & $<80 \%$ & & $\begin{array}{l}\text { Alternating sandstones, mudstones and occasional } \\
\text { muddy sandstones }\end{array}$ \\
\hline $\mathrm{D}$ & & $0-20 \%$ & $>40 \%$ & $<80 \%$ & & $\begin{array}{l}\text { Silstone, muddy siltstone and alternating silstones } \\
\text { and mudstones }\end{array}$ \\
\hline $\mathrm{E}$ & & $<5 \%$ & $<40 \%$ & & $<95 \%$ & Claystone \\
\hline $\mathrm{F}$ & \multicolumn{5}{|c|}{ Undetermined ratios } & Chaotic deposits \\
\hline G & & & & & $>90 \%$ & $\begin{array}{l}\text { Hemipelagic sediments with terrigenous } \\
\text { components }\end{array}$ \\
\hline
\end{tabular}

15 groups were able to be differentiated by internal composition and texture. "Disorganized" facies refers to a group that does not have a clear stratification, such as conglomerate without sedimentary structures, massive sandstone, and bioturbated siltstone and mudstone. "Organized" facies is a group rocks which have a good stratification (bedding), graded bedding, parallel lamination, and cross-lamination. Fifty-nine other individual facies are distinguished based on their texture, internal structure, composition, and thickness of the layers.

\section{Research Methodology}

The method used in this study includes field work, data analysis and interpretation in the studio. Fieldworkinclude outcrops observation, sampling, and detailed outcrop documentation in form of photographs and sketches and measurements. Analysis and data processing has been carried out in the laboratory, such as the sedimentology analysis and facies analysis.

\section{Results and Discussion}

\subsection{Facies Grouping}

The used data is based on results the measured stratigraphic section and lithological observations on Tajum River (Figure 2). Based on Stow classification (1985), the Halang Formation exposed in the study area is divided into more detailed facies (Table 2). 


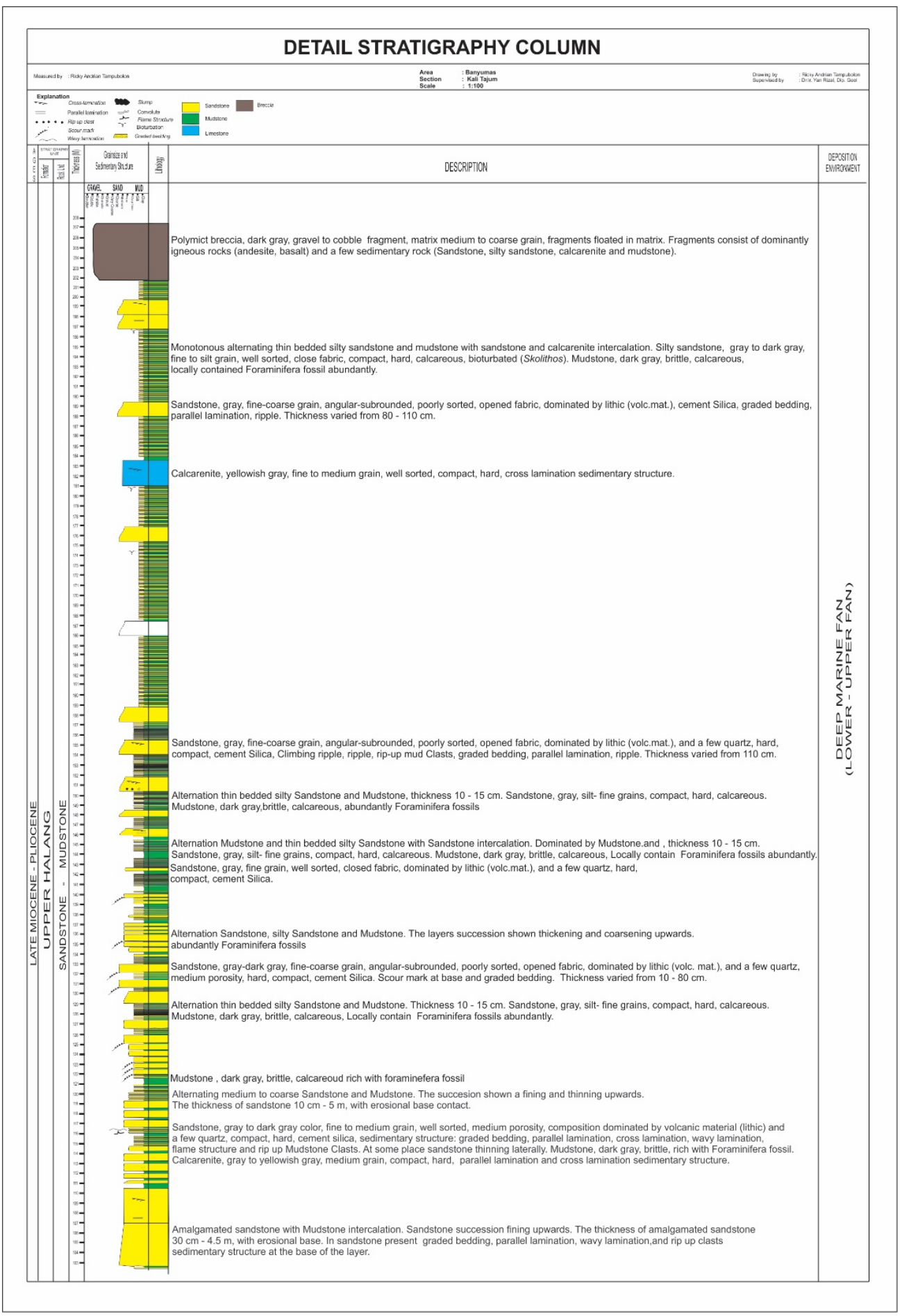




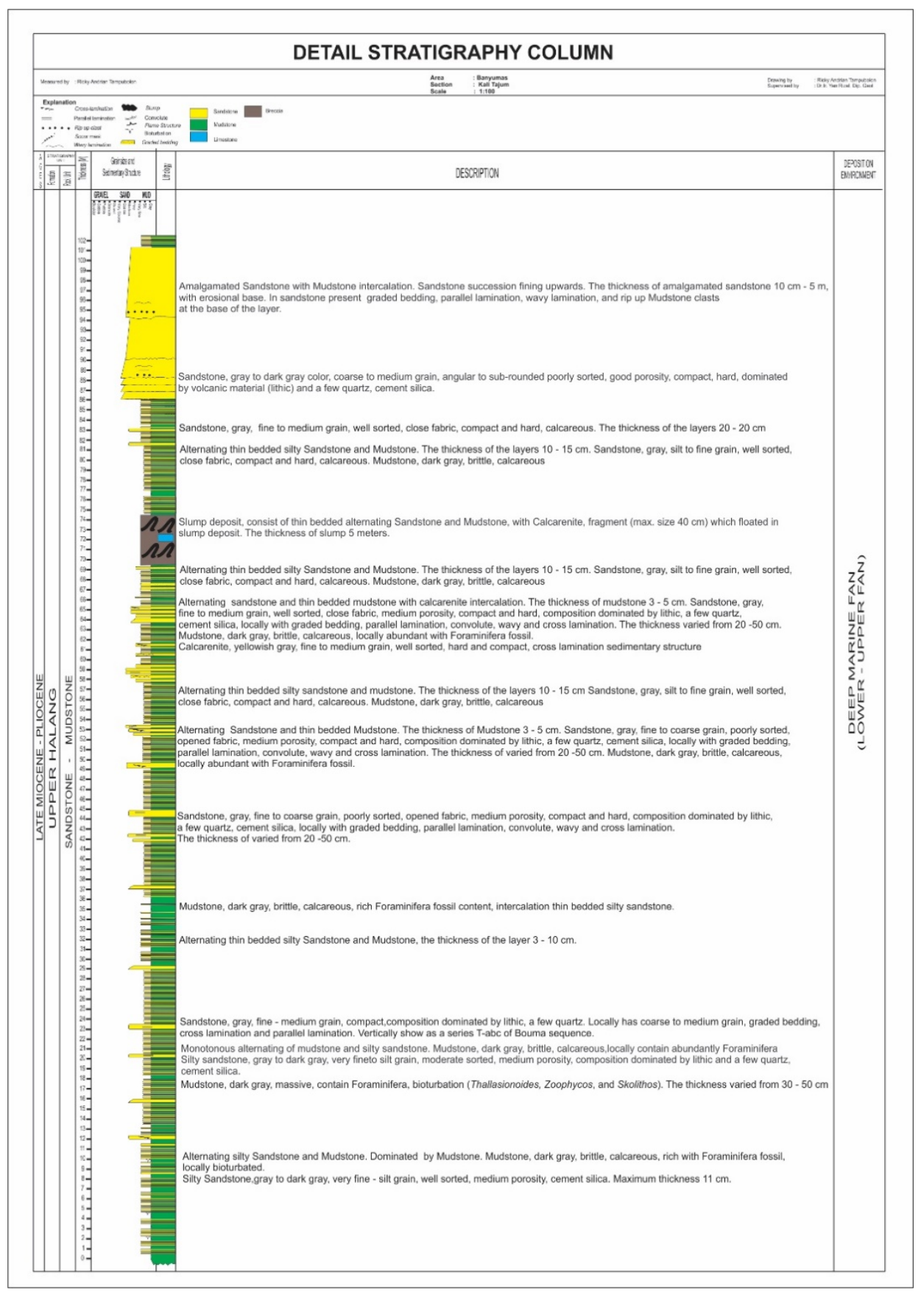

Figure 2. Detail Stratigraphy column of Tajum river traverse (Tampubolon, 2014) 
Table 2. Facies Class, Facies Group and their description

\begin{tabular}{|c|c|c|c|}
\hline $\begin{array}{c}\text { Facies } \\
\text { Class }\end{array}$ & $\begin{array}{l}\text { Facies } \\
\text { Group }\end{array}$ & Description & Interpretation \\
\hline $\mathrm{E}$ & E1 & $\begin{array}{l}\text { Alternating mudstone and thin layered silty sandstone. Mudstone, dark gray, } \\
\text { massive, calcareous, contain foraminifera, bioturbation (Thallasionoides, } \\
\text { Zoophycos, and Skolithos) thickness } 40-60 \mathrm{~cm} \text {. } \\
\text { Silty sandstone, gray to dark gray color, fine to silt grain, angular, moderate } \\
\text { sorted, medium porosity, contain microfossil fragments, lithic and a few quart } \\
\text { (Figure 11). The thickness of sandstone ranges from } 10-30 \mathrm{~cm} \text {. The composite } \\
\text { thickness } 5-13 \mathrm{~m} .\end{array}$ & $\begin{array}{l}\text { Hemipelagic sediment and alternation of suspention } \\
\text { product of low energy turbidity current }\end{array}$ \\
\hline $\mathrm{D}$ & D2 & $\begin{array}{l}\text { Alternation of very fine sandstone and mudstone. The thickness of sandstone } \\
\qquad 10-13 \mathrm{~cm} \text {, composite thickness } 4-8 \mathrm{~m} \text {. } \\
\text { Alternation silty sandstone and mudstone. Clearly bedding plane, thickness of } \\
\text { sandstone } 2-3 \mathrm{~cm} \text {, composite thickness } 1-2 \mathrm{~m} \text {. }\end{array}$ & $\begin{array}{c}\text { Product of turbidite deposit of relatively slow current, } \\
\text { usually as end phase of turbidite process. }\end{array}$ \\
\hline $\mathrm{C}$ & $\mathrm{C} 2$ & $\begin{array}{l}\text { Silty to fine Sandstone, gray, compact, thickness } 60 \mathrm{~cm} \text {. } \\
\text { Sandstone, gray, fine to medium grain, sub-angular to sub-rounded, moderate } \\
\text { sorting, compact, cross- and parallel lamination sedimentary structure. } \\
\text { Thickness } 10 \mathrm{~cm}-1 \mathrm{~m} . \\
\text { Calcarenite, light gray, fine to medium grain, compact and hard, parallel } \\
\text { lamination. }\end{array}$ & $\begin{array}{l}\text { Sediment of classical turbidite, which deposited in } \\
\text { non-channelized turbidite or at overbank of channel }\end{array}$ \\
\hline B & B1 & $\begin{array}{l}\text { Sandstone, gray, coarse to very coarse grain, amalgamated, and scour mark, } \\
\text { rip-up clast at the base of the layer, unclear stratification. } \\
\text { Sandstone, medium to coarse grain, graded bedding, parallel lamination, cross } \\
\text { lamination sedimentary structure. At some place present mud clast at the lower } \\
\text { part of the bedding. Thickness } 2-6 \mathrm{~m}\end{array}$ & $\begin{array}{l}\text { Non-classic turbidite which associated with channel } \\
\text { and frontal splay. This sediment deposited under } \\
\text { condition rapid current or high energy turbidity current }\end{array}$ \\
\hline A & A1 & $\begin{array}{l}\text { Clast supported Conglomerate, dominated by clast of andesite and basalt } \\
\text { fragments (Diameters 7-8 cm), non-oriented fragment (disorganized). } \\
\text { Thickness 3-6 m. }\end{array}$ & $\begin{array}{l}\text { In-channel deposit of sub-marine fan sediment which } \\
\text { produced by debris flows mechanism }\end{array}$ \\
\hline G & G1 & $\begin{array}{l}\text { Mudstone, gray - dark gray, strongly calcareous, rich with Foraminifera fossil } \\
\text { and bioturbation. Thickness } 30-50 \mathrm{~cm} .\end{array}$ & $\begin{array}{l}\text { Hemipelagic sediment at the end phase of low energy } \\
\text { turbidity current. }\end{array}$ \\
\hline $\mathrm{F}$ & F2 & $\begin{array}{l}\text { Slump deposit of thin-bedded turbidite with calcarenite fragments. Thickness } \\
\qquad 5 \mathrm{~m} .\end{array}$ & Slump of channel-overbank sediment \\
\hline
\end{tabular}

\subsection{Facies Association}

The following five facies association can be determined in the study area, they are:

\subsubsection{Basin Plain Facies Association}

\section{a. Description:}

The basin plain facies association generally occupy in the lower part of the detail stratigraphic column (Figure 2). This facies association consists of E1 facies, which is heavily bioturbated (Figure 3 and Figure 4) build up by monotonous series of alternation of mudstone and thin layered silty sandstone predominated by mudstone. The thickness of this facies association totally about $11.8 \mathrm{~m}$. The mudstone is dark gray, brittle, calcareous, contain rich foraminifera fossil, and locally rich with bioturbation (Thallasionoides, Zoophycos, and Skolithos), thickness may ranges between $40-60 \mathrm{~cm}$. Silty sandstone (feldspathic wacke), gray to dark gray color, fine to silt grain, sub-rounded, well sorted, medium porosity, contain microfossil fragments, feldspar and plagioclase, and quartz (Figure 5). The thickness of sandstone ranges from $10-30 \mathrm{~cm}$.

\section{b. Depositional Environment:}

The vertical succession of the basin plain facies association is dominated by alternating mudstone and thin layered sandstone. The mudstone deposited as pelagic sediment where the sedimentation is controlled by suspension process so that life can thrive that shown by presence of many bioturbation (Thallasionoides, Zoophycos, and Skolithos) and abundant of foraminifera fossils. Thin layered sandstone is interpreted to be 
deposited under control of low velocity traction current cross lamination and parallel lamination sedimentary structure are likely product of low energy turbidity current. Base on above sediment character can be interpreted that the environment deposition is basin plain non-channelized submarine fan (Shanmugam et al, 1985).

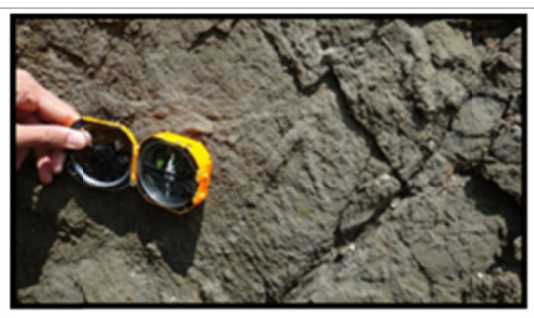

(a)

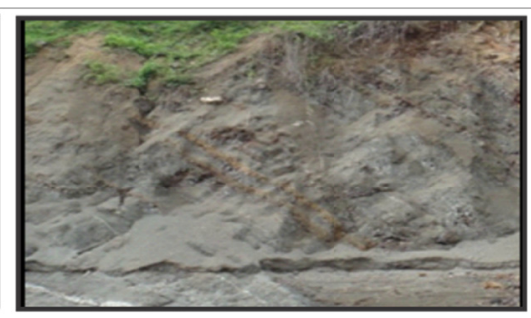

(b)

Figure 3. a. Outcrop of alternating mudstone and sandstone (Facies C1)

b. Mudstone outcrop with Thallasionoides bioturbation

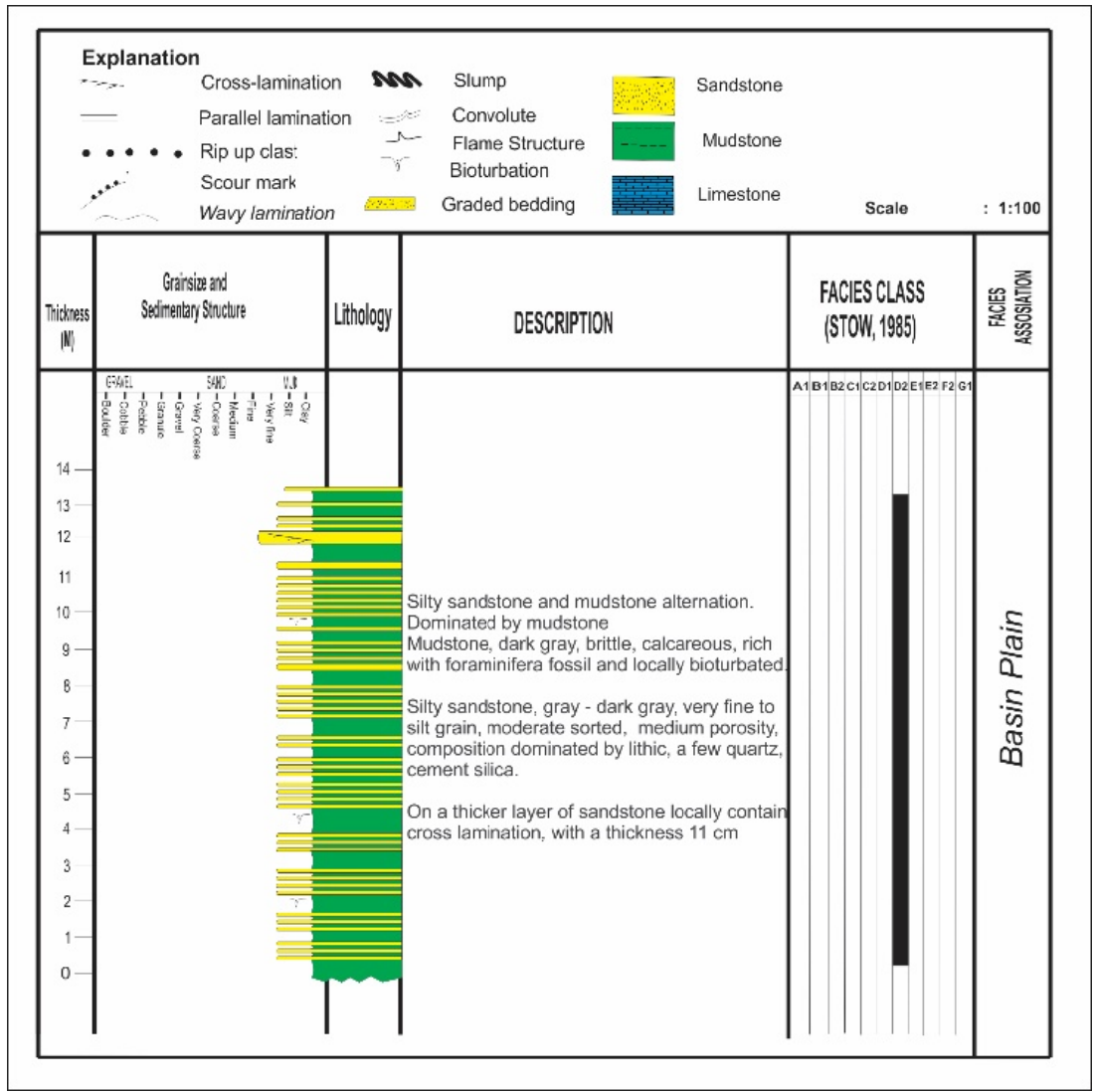

Figure 4. Stratigraphy Section of the basin plain facies association

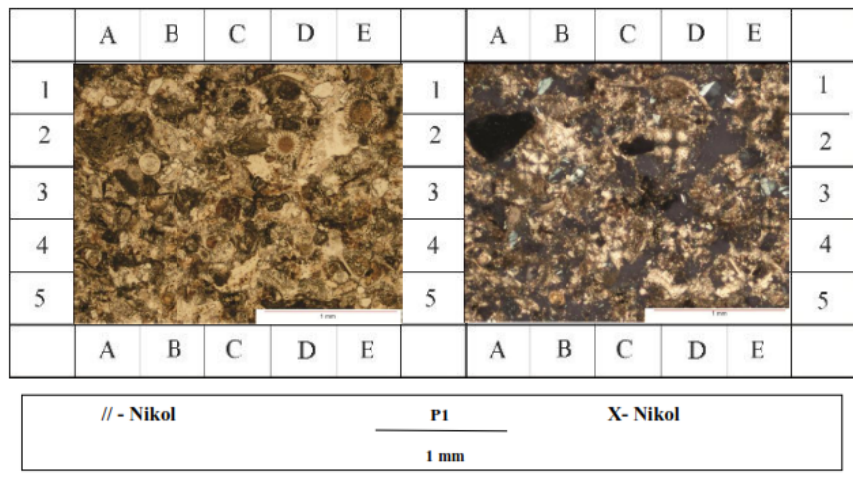

Figure 5. Thin section of Silty sandstone (Feldspathic wacke) 


\subsubsection{Channel-Overbank Facies Association}

\section{a. Description:}

This channel-overbank facies association consists of D1, C2 and G1 facies. Each facies can be distinguished by thin alternation of silty sandstones and mudstone. Facies D1 characterized by alternation of very fine sandstone and mudstone. The sandstones (feldspathic wacke) are gray to dark gray color, fine sand to silt size grains, well sorted, medium porosity, composition dominated by quart, feldspar, plagioclase and fossil fragment (Figure 6). In general, this series vertically shows a monotonous succession and thinning laterally (Figure 7 and 8 ). The mudstone often observed as dark gray, brittle, calcareous, locally abundant with foraminifera fossils.

The ratio of sandstone to mudstone is about $20 \%$. The total thickness of this facies association in one series can reach $9 \mathrm{~m}$.

Facies C2 consists of gray sandstone, fine to medium grain, compact. Intercalation of coarse-medium grained sandstones with graded bedding, parallel lamination, and cross-lamination sedimentary structures were observed as a part of a series indicating T-abc of Bouma sequence. The total thickness of this facies varied from $10 \mathrm{~cm}$ to $1 \mathrm{~m}$.

Facies G1 is characterized by dark gray mudstone, dark gray, massive, contain Foraminifera fossils and bioturbated (Thallasionoides, Zoophycos, and Skolithos). The thickness ranges from $30-50 \mathrm{~cm}$, often present as intercalation layer in alternation silty sandstone and mudstone.

b. Depositional Environment:

Based on a sediment characters and their vertical succession, which show monotonous alternating silty sandstone (Facies D1) and coarse - medium sandstone with cross-lamination, parallel lamination and graded bedding sedimentary structure (Facies C2), mudstone with their fossil content such as bioturbation and rich with foraminifera, the depositional environment of this facies association is interpreted to be channel-overbank of a submarine fan. According to Mutti and Nomark (1987), this succession is commonly found in the overbank deposit of channel on deep sea fan. "Overbank" itself refers to the depositional environment that is periphery of the channel, therefore Lowe (1982) called a deposits as a results of a non-channelized turbidite, in this deposition system is very common present a Bouma sequences.

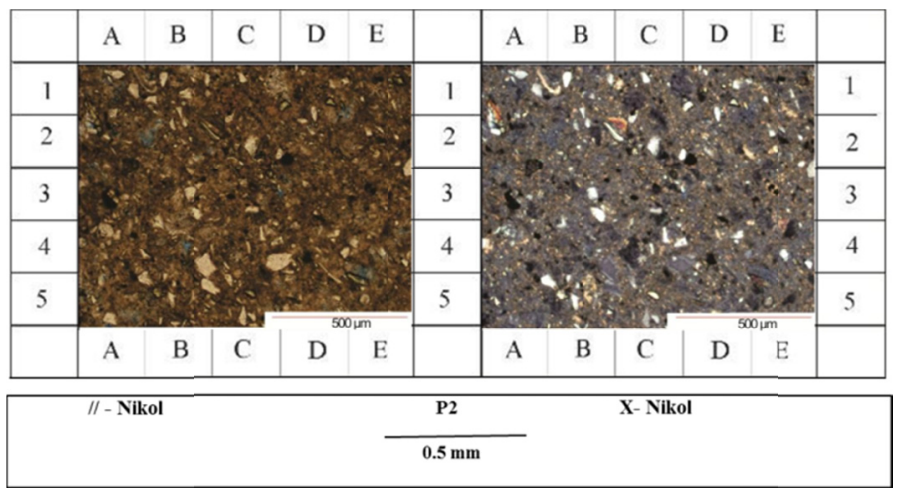

Figure 6. Petrography thin section of Sandstone (Feldspatic wacke) (C2 facies) 


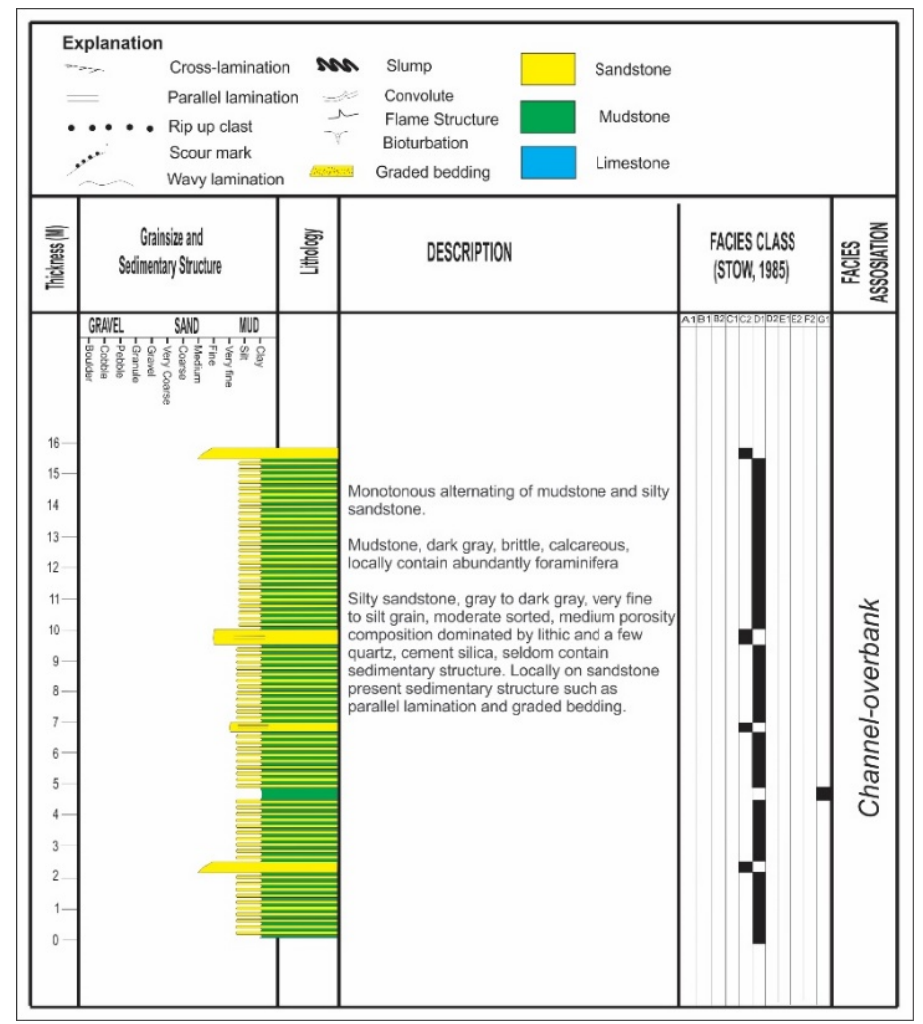

Figure 7. Stratigraphy section of channel-overbank facies association

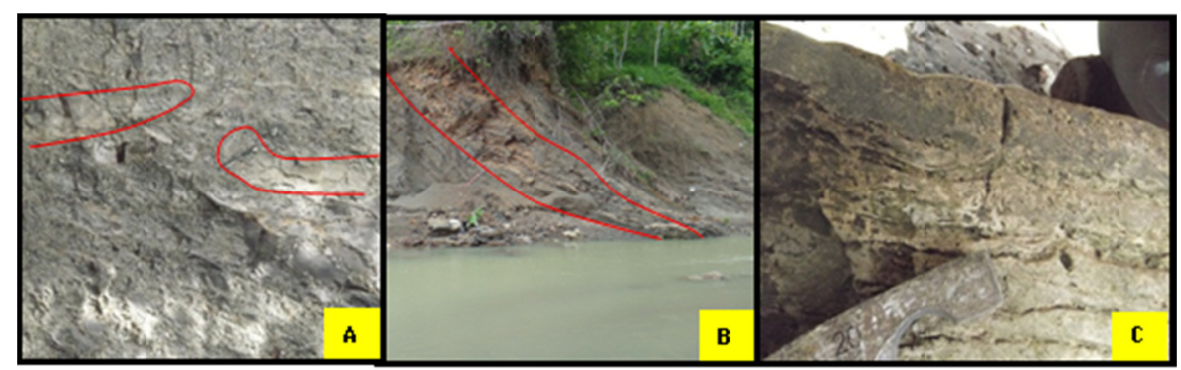

Figure 8. Outcrops of Sandstone, which show thinning laterally $(a, b)$,

(c) cross-lamination sedimentary structure

\subsubsection{Channel-fill Fasies Association}

\section{a. Description:}

Channel fill facies association consists of facies B1, B2, C1, C2, D2, and E1. Following a detailed measured stratigraphic section, this facies association is divided into two parts; Lower and Upper Part. The thickness of this facies associations varied from $14 \mathrm{~m}$ to $20 \mathrm{~m}$ with sandstones ratio about $70-90 \%$. The lower part consists of sandstone and compiled by facies B1 and facies B2 (Figure 9, 10 and 11). Facies B1 is characterized by gray to dark gray sandstones (lithic wacke), very coarse to medium grained, poorly sorted, angular to sub angular, good porosity, compact, with clast composed of mainly volcanic material (lithic) and a few quartz, silica cement. Thickness ranges between $2 \mathrm{~m}$ to $6 \mathrm{~m}$.

Facies B2 consist of amalgamated sandstone with mudstone intercalation. The sandstone succession show fining upwards. The thickness of amalgamated sandstone varied from $10 \mathrm{~cm}$ to $5 \mathrm{~m}$ often found with erosional base. The grey sandstone is medium to coarse grained, angular to sub-angular, moderate - poorly sorted, clasts mainly composed of lithic (volcanic rocks), a few quartz, silica cement, compact. Graded bedding, parallel lamination, wavy lamination and rip up clast and show a series of T-abc of Bouma sequence often observed in the sequence. 


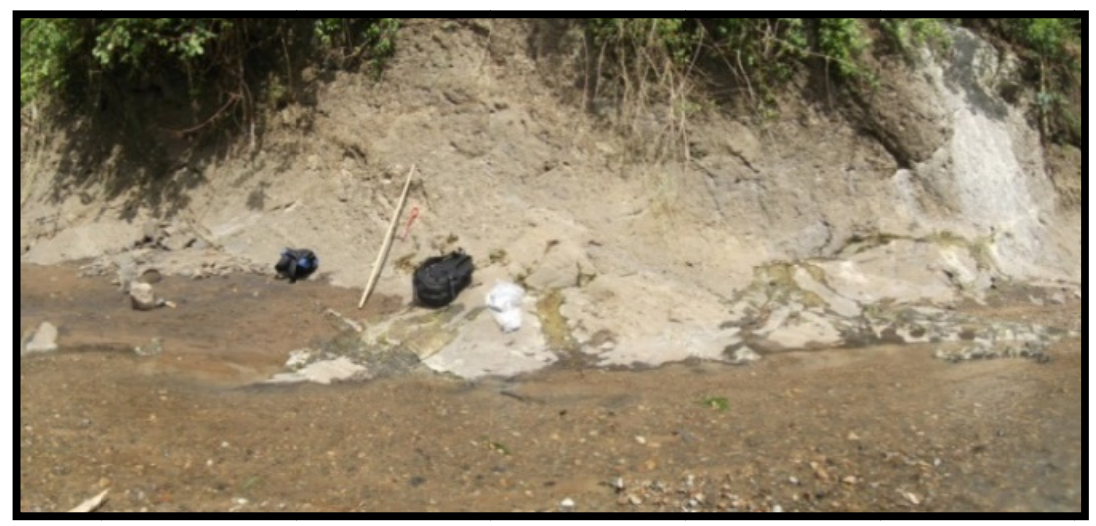

Figure 9. Outcrop of sandstone (B1 Facies) in Tajum River

The upper part of the section consists of B1, B2, C2, D2 and E1. Facies B1 is characterized by gray sandstones, very fine to very coarse grained, amalgamated, typified by graded bedding and scour mark, rip up clast sedimentary structure, unclear stratification. Facies B2 is characterized by medium t- coarse grained sandstones, graded bedding, parallel lamination, and cross lamination are common sedimentary structures. The sequence locally contains mud clast at the base of the bedding. Facies $\mathrm{C} 2$ consists of gray sandstones, gray, fine to medium grained, compact, and showed a series of T- abc of Bouma sequence. These sandstones facies thickness reach tens of centimetres. Facies D2 consists of alternation of thinly bedded $(2-3 \mathrm{~cm})$ silty sandstones and mudstones with clear bedding plane Facies E1 consists of bioturbated dark gray mudstone, massif, contains foraminifera and trace fossils (Thallasionoides, Zoophycos, and Skolithos) thickness 40-60 cm.

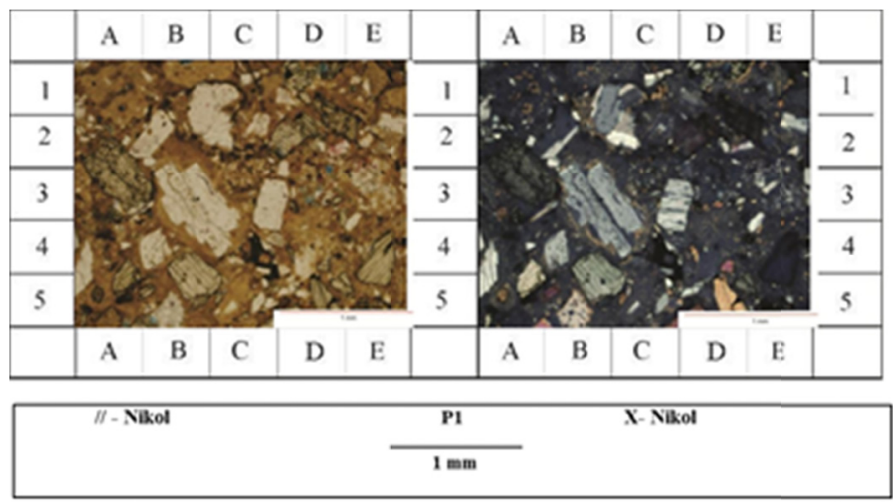

Figure 10. Petrography thin section of Sandstone (Lithic wacke) (B1 facies)

\section{b. Depositional Environment:}

The vertical succession of a lower part of the stratigraphy is interpreted as product of turbidity flow in mid fan channel of deep marine fan that comparable to non-classical turbidite deposition (Mutti and Luchi, 1972). The upper part of the section showed more variation of the facies, which is dominated by sandstone. Based on a pattern of vertical succession and its sedimentary character is interpreted as product of turbidity flow, which lasted in outer fan channel of deep marine fan. 


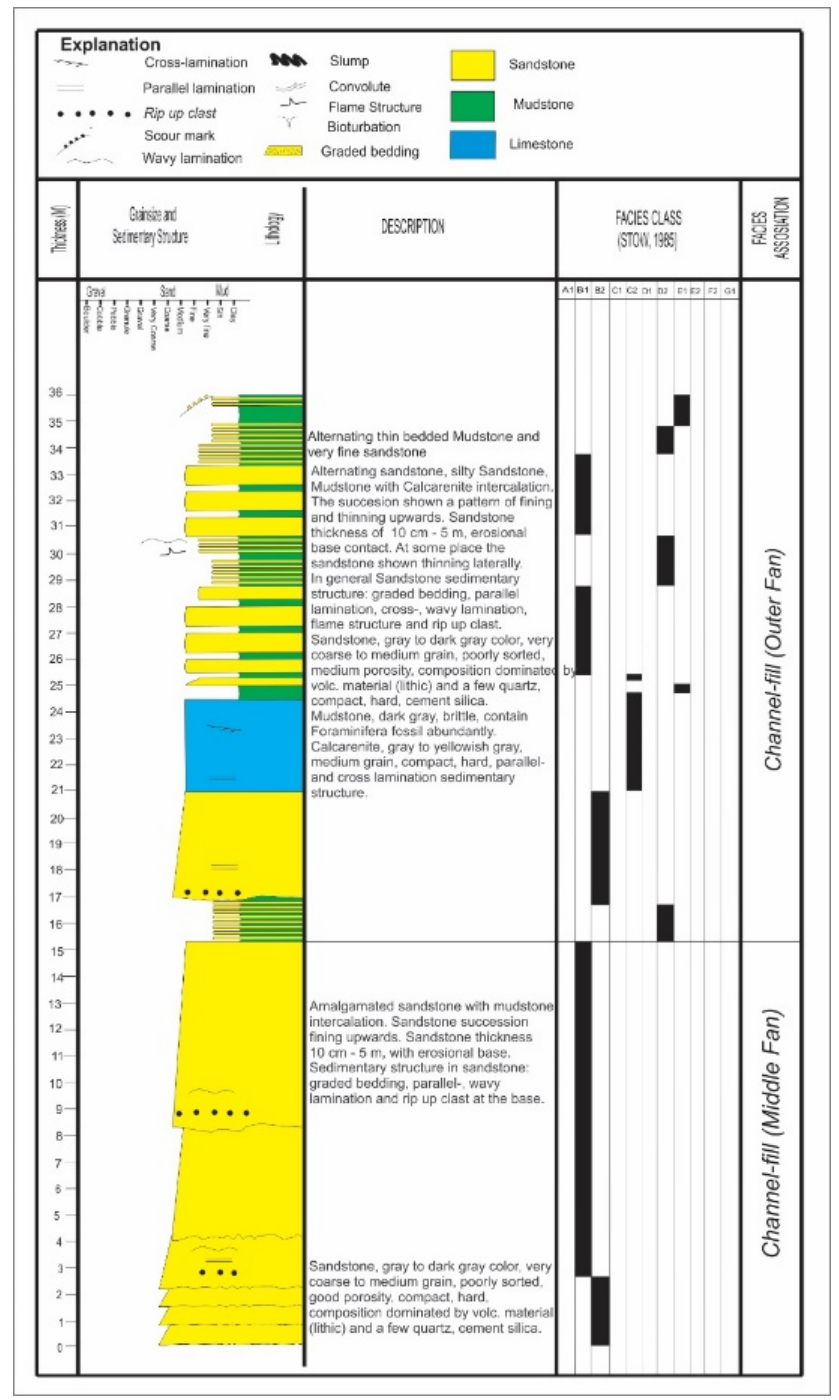

Figure 11. Stratigraphy Section of channel-fill facies in Tajum River

\subsubsection{Frontal Splay (Lobe) Facies Association}

\section{a. Description:}

This facies association consists of facies B1, C2, D1, D2 and E1. In the vertical succession the sandstone layer generally show coarsening and thickening upward (Figure 12, 13 and 14). Scour marks are commonly observed at the base of the sandstone beds. The total thickness of this facies association is about $18 \mathrm{~m}$, with sandstones ratio about $70 \%$. Facies B1 is characterized by interbeds of sandstone and thin mudstones. Gray to dark gray sandstones (Lithic wacke), fine to coarse grained, poorly sorted, compact, with clasts mainly composed of lithic of volcanic material and few quartz. Common sedimentary structures found in this facies are scour marks and graded bedding. The dark gray mudstone is brittle, calcareous and bioturbated at the upper part.

Facies $\mathrm{C} 2$ consists of grey sandstone, fine to medium grained, compact. Occasional coarse-medium grained layers with graded bedding, parallel lamination, and cross-lamination sedimentary structures were observed representing part of T-abc series of Bouma sequence. D1facies is characterized by alternating silty sandstone and mudstone. D2 facies consists of dense alternating of silty sandstone and mudstone.

E1 facies is characterized by alternated dark gray mudstone and dark gray silty sandstone. The mudstone is massif, contains foraminifera and trace fossils (Thallasionoides, Zoophycos, and Skolithos) with thickness ranges between $40-60 \mathrm{~cm}$. Te silty sandstones isfine sand to silt grained, angular, moderately sorted, medium porosity, contains microfossil fragments, lithic and a few quartz. 


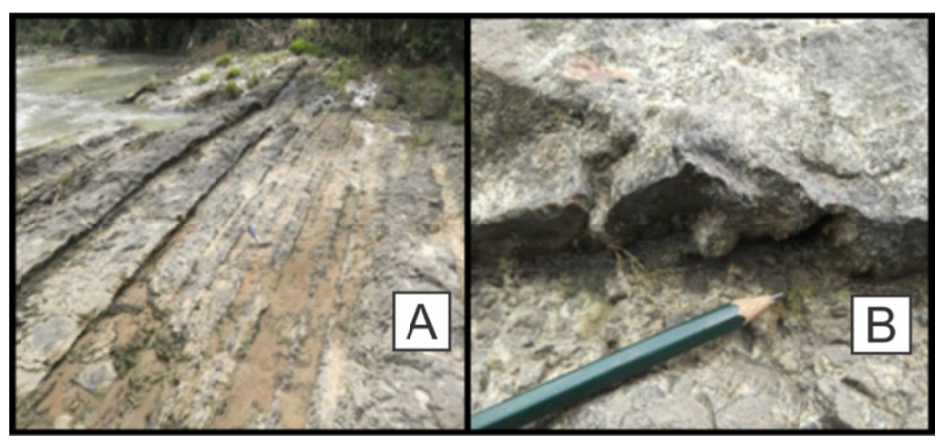

Figure 12. Outcrop of alternating of sandstone and mudstone in Tajum River. (a) Sandstone layer show a thickening and coarsening upward. (b) Scour mark sedimentary structure at the bottom of sandstone layer.

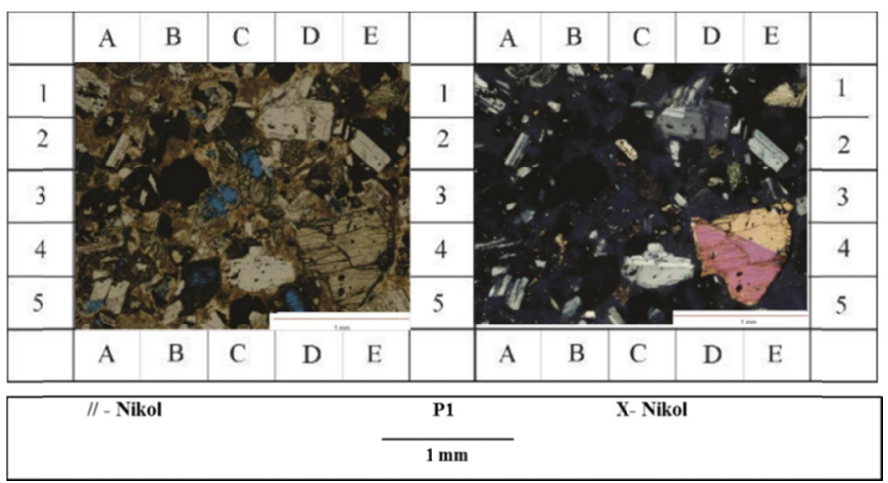

Figure 13. Petrography thin section of sandstone (Lithic wacke) (B1 facies)

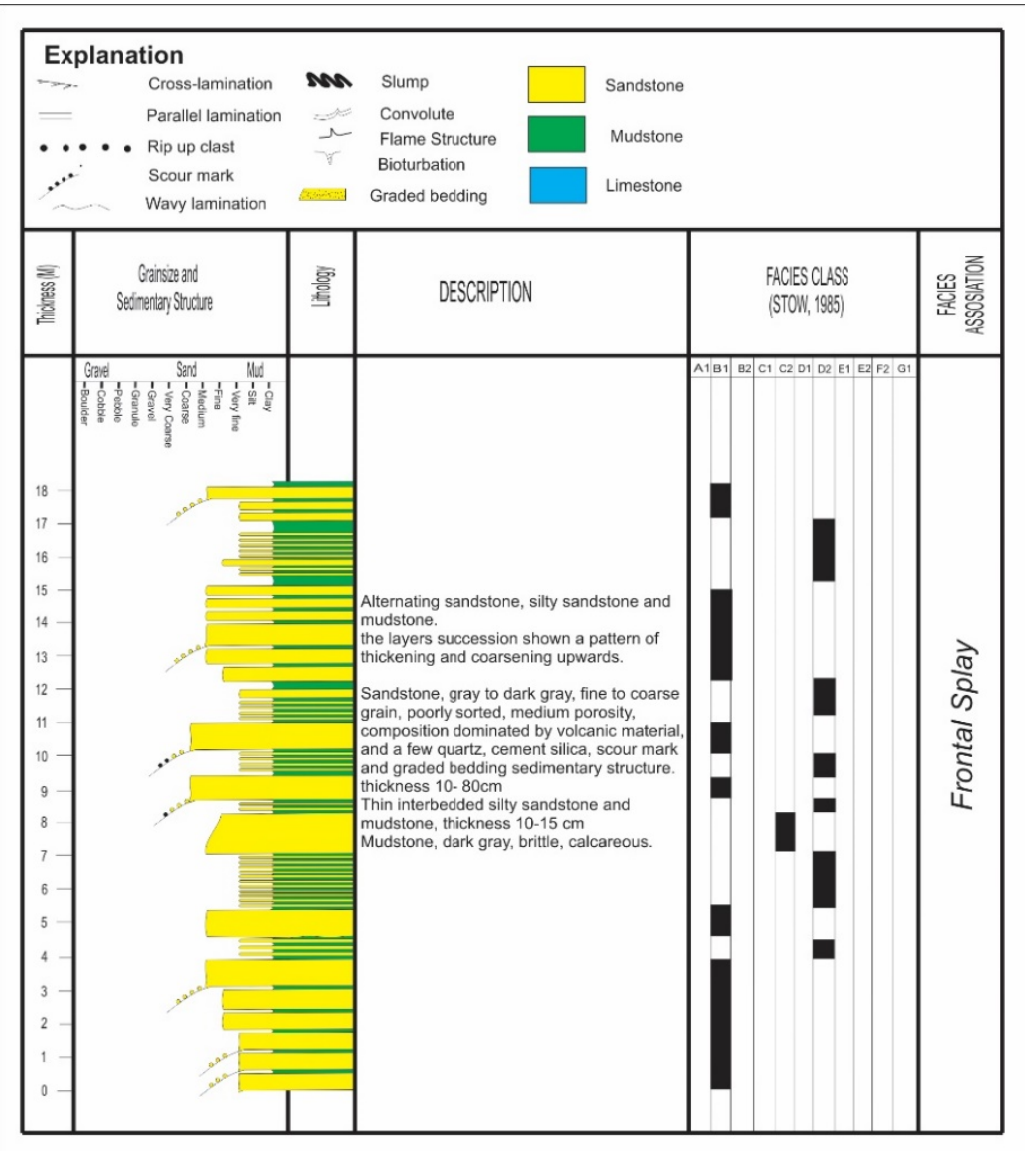

Figure 14. Stratigraphy section of frontal splay facies association 


\section{b. Depositional Environment:}

According to facies association model of deep marine fan (Mutti and Lucchi, 1972), above facies associations are comparable to lobe deposit of the deep sea fan, a lobe position of deep marine fan is at transition point of the channel, where levee as the embankment bypassed by the flow of the turbidite from the channel. The overflow generates a new deposit, so-called lobe (Posamentier and Walker, 2006). Consequently, this lobe deposit will be closely associated with deposit of the channel of deep marine fan. In the study area the lobe deposits encountered stratigraphically above the sediment channel of deep marine fan.

\subsubsection{Crevasse Splay Facies Association}

\section{a. Description:}

Crevasse Splay Facies Association built up by C2 and D2 fasies. C2 facies consists of grey lithic wake sandstones, fine to coarse grained, angular to subangular, poorly sorted, open fabric, moderate porosity. The clasts composed of lithic, plagioclase, and few quartz. Commonly observed sedimentary structures are parallel lamination, climbing ripple laminae, graded bedding and mud clasts. Occasional T-abc series of bouma found in the sequence (Figure 15, 16 and 17). The thickness ranges between $70 \mathrm{~cm}$ to $150 \mathrm{~cm}$. D2 facies consists of alternating thin layered gray silty sandstone and gray mudstone. The silty sandstone is silt to fine grained, compact and hard and calcareous. The mudstone is brittle, calcareous, rich with Foraminifera fossils. Total thickness of this facies association may reach $12.5 \mathrm{~m}$ with sandstone ration about 45\% (Figure 18)

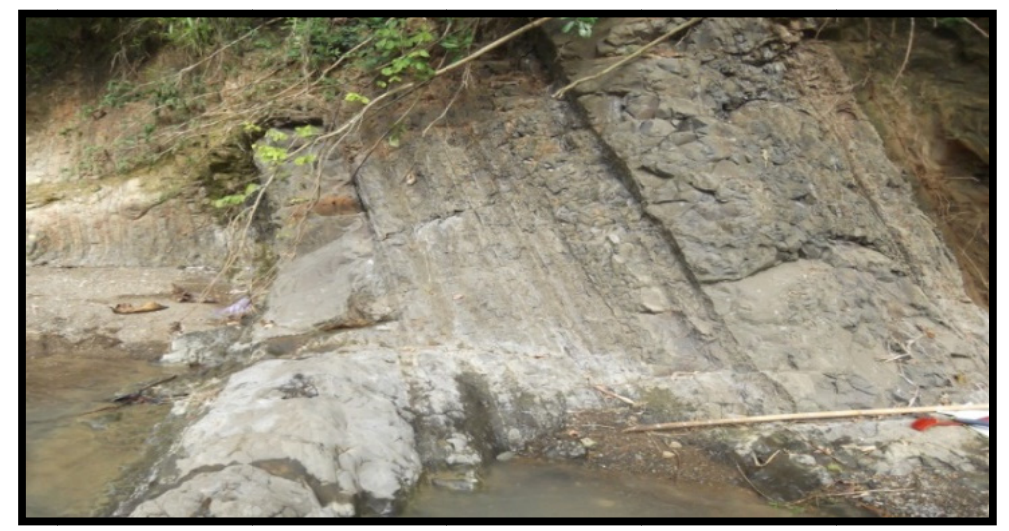

Figure 15. Outcrop of Sandstone (C2 facies)

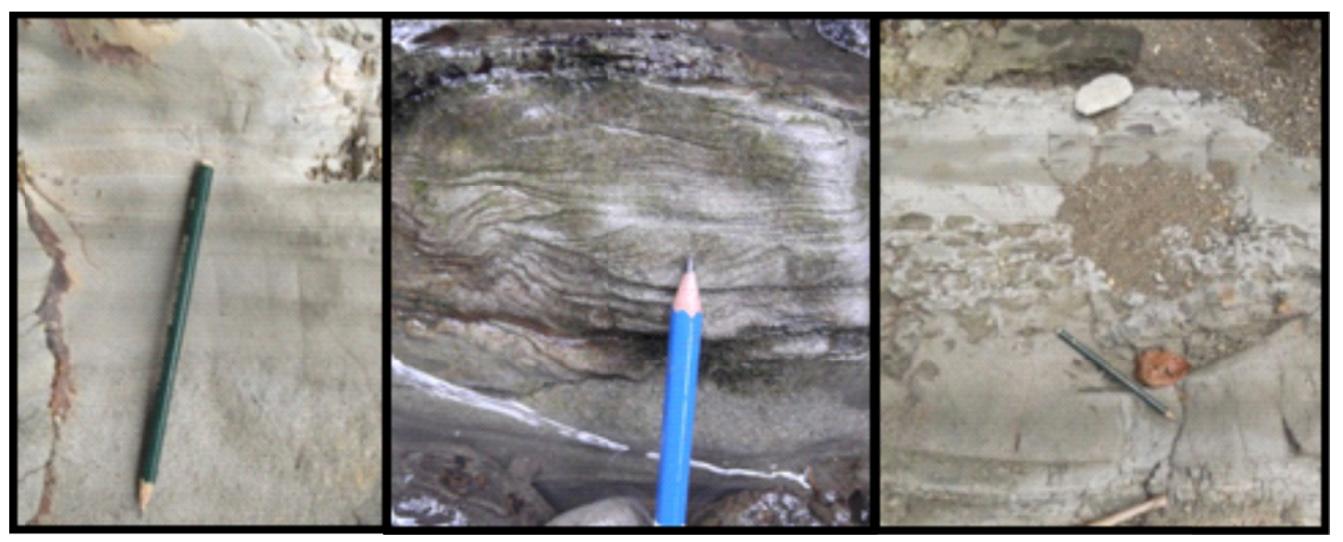

Figure 16. Sedimentary structure of Sandstone (C2 facies)

Graded bedding (left), Climbing ripple (middle), mud clast in Sandstone (right) 


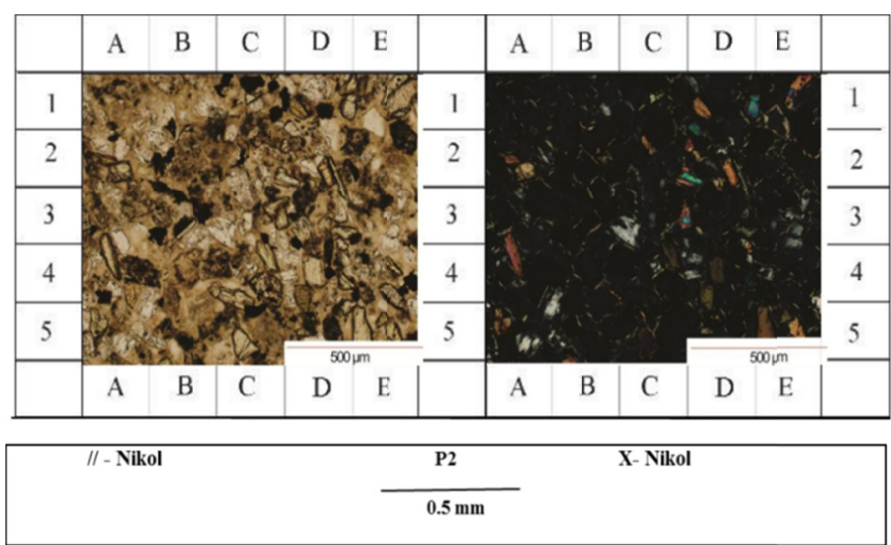

Figure 17. Petrography thin Section of sandstone (Lithic wacke) (C2 facies)

b. Depositional Environment:

It is challenging to distinguish between frontal crevasse splay sediments, the difference lies in the structure and geometry of the deposits. Climbing ripple laminae and mud clasts are common in the crevasse splay (Shanmugam, 2006). The presence of mud clast is a product of erosion of the underlying layer. Climbing ripple sedimentary structures are generally present as a product stream rapid sedimentation. Within the study area was found character sedimentary sequences similar to as described Shanmugam (1985), therefore the facies association found here is comparable to crevasse splay deposit of deep marine fan.

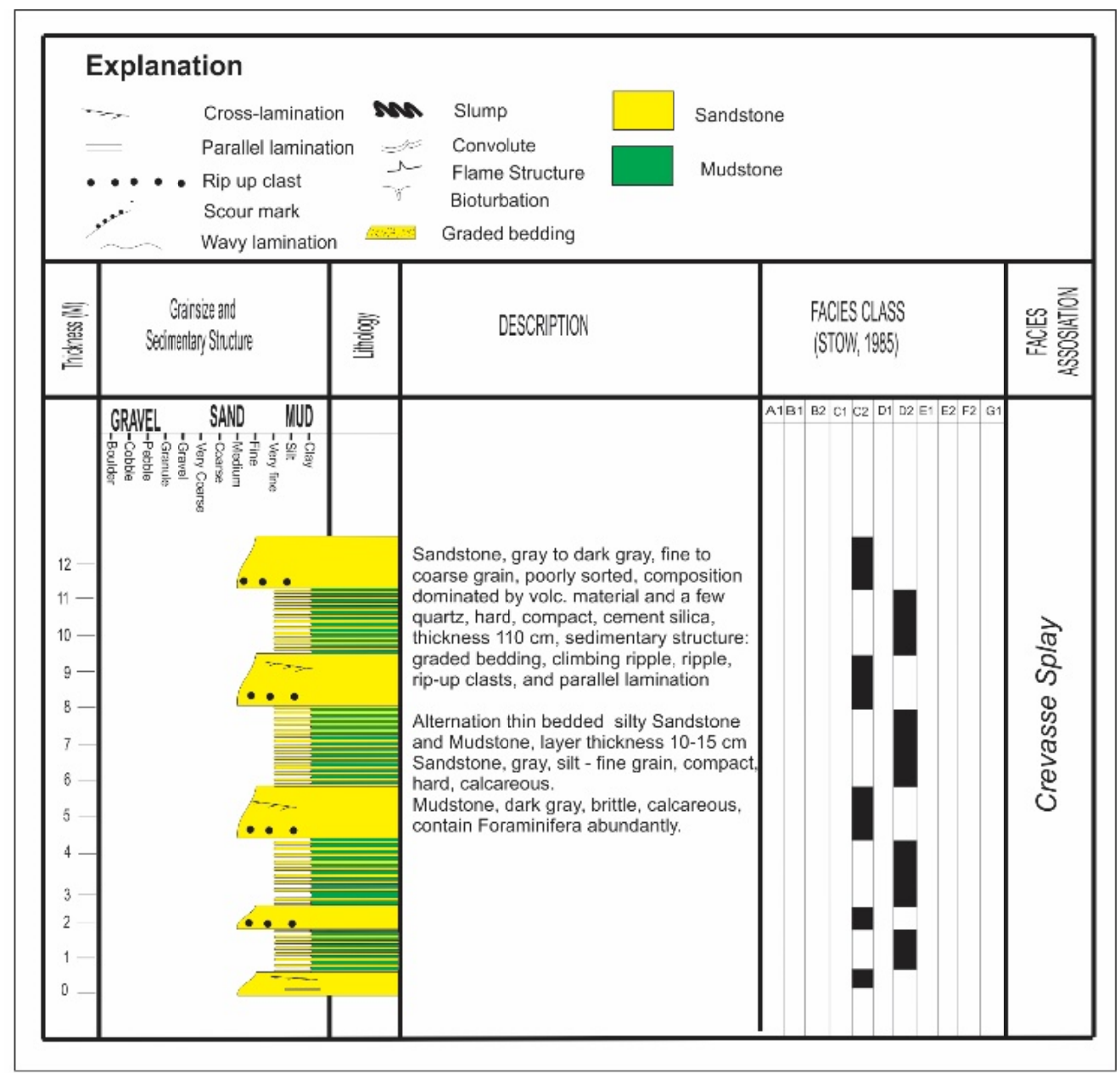

Figure 18. Stratigraphy section of crevasse splay facies association 


\subsubsection{In Channel Facies}

\section{a. Description}

These facies built up by dark gray-gray polymict breccia, massif, fragment consists mostly consist of igneous rock (andesite and basalt) and sedimentary rock (silty sandstone, calcarenite and mudstone), gravel to cobble, angular to sub-rounded floated in matrix (medium to coarse sand) without orientation (unorganized; Figure 19, $20,21)$. The thickness is varied from $3-5.5 \mathrm{~m}$.

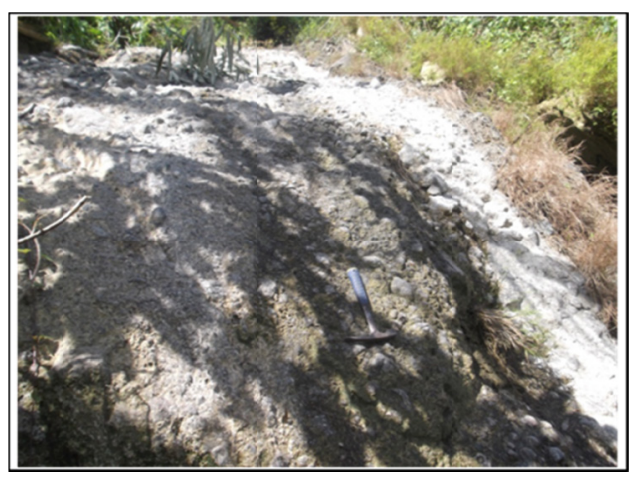

Figure 19. Outcrop of breccia, which shown fragments floated in matrix

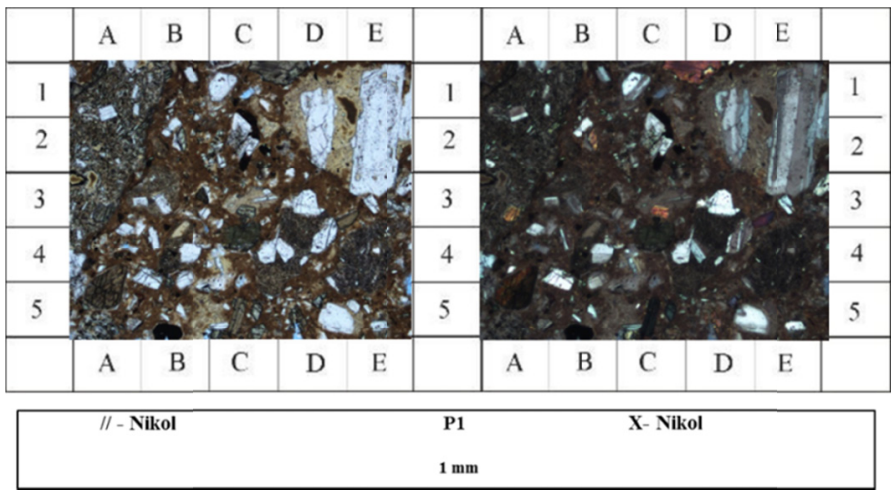

Figure 20. Petrography thin section of matrix of breccia (Feldsphatic wacke)

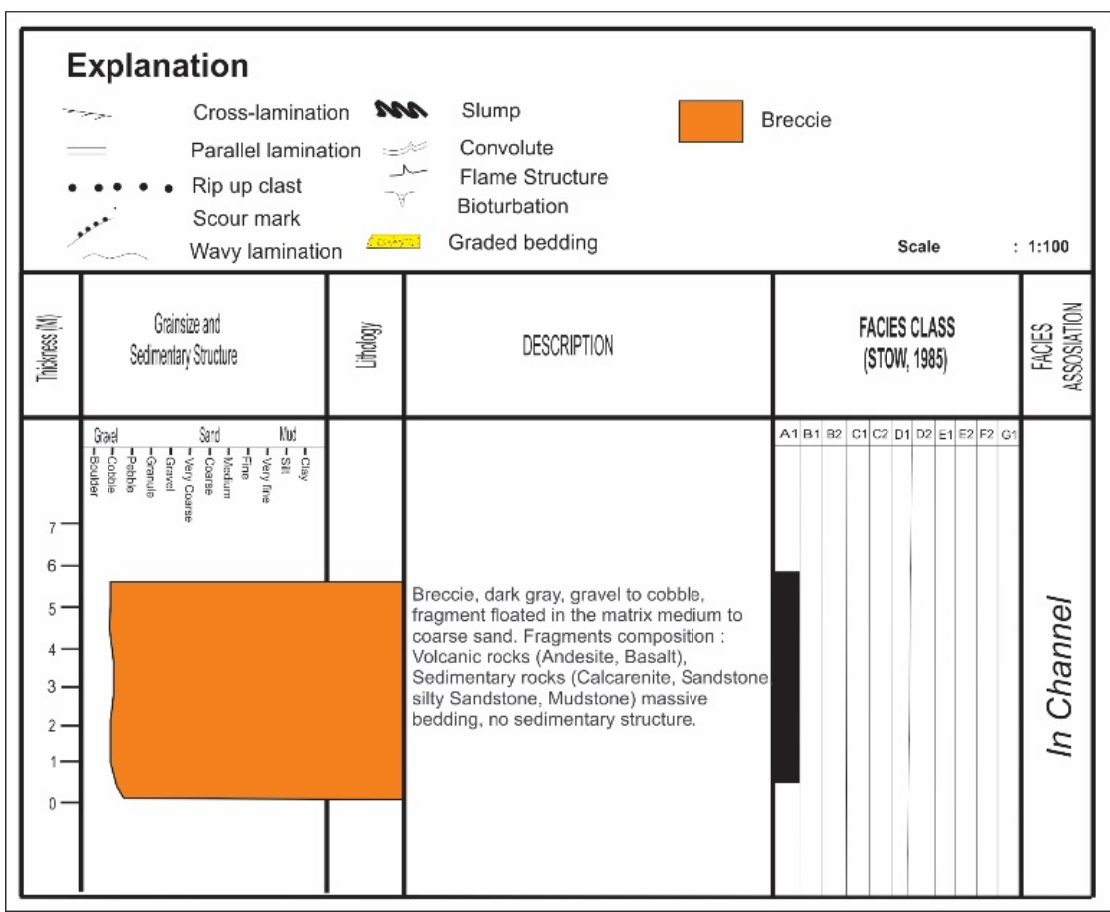

Figure 21. Stratigraphy profile of Breccia 


\section{b. Depositional environment:}

Based on it textural character, the above breccia is nterpreted as a product of debris flow sedimentation, which usually present in channel of deep marine fan system.

\subsubsection{Slump Facies}

\section{a. Description:}

The slump facies is characterized by chaotic layers of fine-grained sediments, which by lithology consists of calcarenite, silty sandstone and mudstone, where the calcarenite and silty sandstone present as fragment in mudstone (Figure 22). The thickness of this sequence is about $5 \mathrm{~m}$.

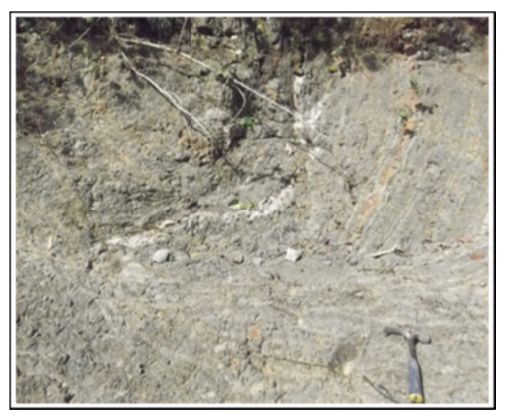

Figure 22. Outcrop of slump deposit, which seen as chaotic layer

\section{b. Depositional Environment:}

The association between silty sandstone and calcarenite is interpreted to be deposited in channel overbank environment.

\section{Discussion}

\subsection{Vertical Succession of Tajum River Traverse}

The vertical facies architecture of the Halang Formation in the study area are as follow: the base formed by the basin plain facies before it passes vertically into channel-overbank facies. Second cycle of basin plain facies and channel-overbank facies occurred then followed by slumps, channel overbank, channel fill (mid fan and outer fan) and frontal splay facies. The third succession of basin plain, crevasse splay, channel overbank and in channel facies occurred at the very top of the sequence (Figure 23). In general, the vertical succession at Tajum River indicated a change of sub-basin depositional environment from basin plain to channel fill and channel-overbank including frontal splay and crevasse splay (Figure 24). Overall sediment succession in the study area indicates a transgressive sequence that can be caused by e morphological changes of deep marine fan which probably influenced by local tectonic during sedimentation takes place.

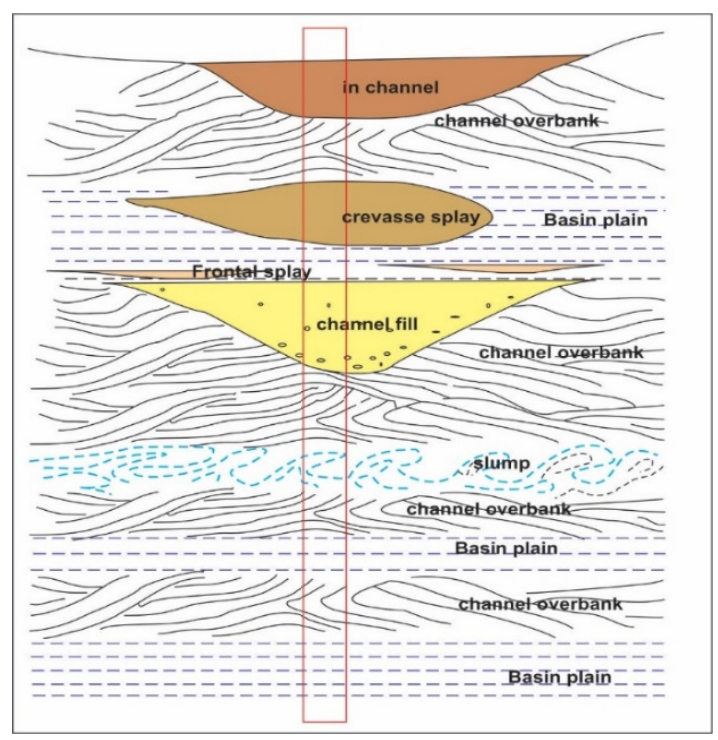

Figure 23. Schematic Diagram of the facies association deposition environment in deep marine fan 


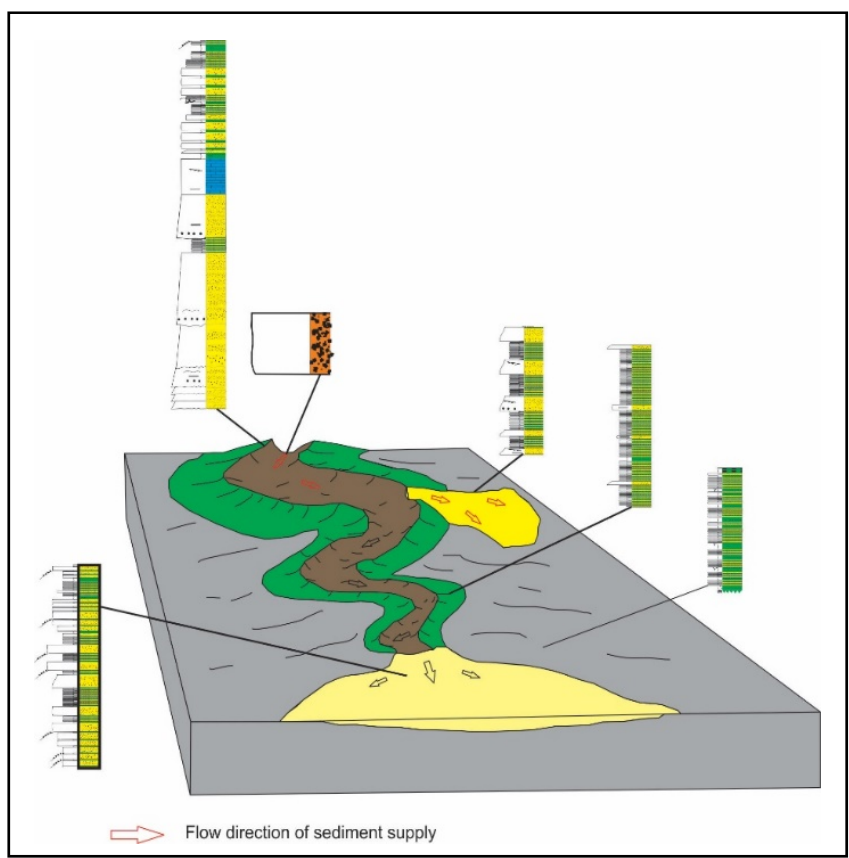

Figure 24. Vertical Succession of the facies association (red color) and Interpretation of it deposition environment at Tajum river

\section{Conclusions}

The following conclusions can be drawn from the data and interpretation:

1. Three cycles of facies association can be determined from the Halang Formation in the study area:

a. basin plain facies, channel-overbank facies

b. basin plain facies, channel-overbank facies, slump, channel-overbank facies, channel-fill facies (mid fan and outer fan), frontal splay facies

c. basin plain facies, crevasse splay facies, channel-overbank facies and in channel facies

2. This vertical succession indicates a change of depositional environment from basin plain to channel-overbank channel fill and in channel.

3. The environment deposition of facies association showed a transgressive phase which may be caused by the change of morphology of deep marine fan that probably influenced by local tectonics during sedimentation process takes place.

\section{References}

Abdurrokhim, Firmansyah, Y. Natasia, N. \& Saputra, M. (2017). Lithofacies of the Halang Formation in the Cijurey River-Majalengka, Journal of Geological Science and Applied Geology, 2(3), E-issn: 2579-3136, Padjajaran University.

Ardenta, H. N., Rohmana, R. C., Fadhlillah, M. W., Ghufrani, P. M. \& Achmad, A. (2016). Development of deep water facies and paleogeography model in fore arc basin : An Example from Halang Formation, Banyumas sub basin, Central Java, Proceeding Seminar Nasional Kebumian ke -9 Peran Penelitian Ilmu Kebumian Dalam Pemberdayaan Masyarakat. Grha Sabha Pramana.

Fanani, Z. (2012). Geologi dan Potensi Batuan Induk sub-cekungan Banyumas, Daerah Lumbir dan Sekitarnya, Banyumas, Jawa Tengah. UPN Yogyakarta.

Kastowo \& Suwarna, N. (1996). Peta Geologi Bersistem Indonesia, Lembar Majenang, Skala 1:100.000, Pusat Penelitian dan Pengembangan Geologi, Bandung.

Lowe, D.R. (1982). Sediment Gravity Flows: II. Depositional Model with Special Reference to the Deposits of High Turbidity Currents, Journal of Sedimentary Petrology, 52, 279-297. https://doi.org/10.1306/212F7F31-2B24-11D7-8648000102C1865D

Mulhadiyono, A.A. (2006). Petroleum Possibilities of the Banyumas Area, Proceeding Indonesia Petroleum Association, $2^{\text {nd }}$ Annual Convention, 121-129. 
Mutti, E. \& Nomark, W.R. (1987). Comparing Example of Modern and Ancient Turbidite Systems: Problems and Concept, in Deep Water Clastic Models and Case Histories, Legget, J.R., Zuffa, G.G., Editor, Graham and Trotman, London, 1-38. https://doi.org/10.1007/978-94-009-3241-8_1

Mutti, E. \& Ricci Lucchi, F. (1972). Turbidites of The Northen Apennines: Introduction to Facies Analysis, International Geology Review, 20, 125-166. https://doi.org/10.1080/00206817809471524

Pickering, K.T., Stow. D.A.V., Watson, M. \& Hiscott, R.N. (1986). Deep-water Facies, Process, and Models: A Review and Classification Scheme for Modern and Ancient Sediments, Earth Science Review, 22, 75-174. https://doi.org/10.1016/0012-8252(86)90001-2

Posamentier, H.W. \& Walker, R.G. (2006). Deep-water Turbidite and Submarine Fans, SEPM (Society for Sedimentary Geology), 84, 399-520. https://doi.org/10.2110/pec.06.84.0399

Praptisih dan Kamtono. (2011). Fasies Turbidit pada Formasi Halang di Daerah Ajibarang , Jawa Tengah, Jurnal Geologi Indonesia, 6(1), 13-27. Puslit Geoteknologi-Lipi Bandung.

Reading, H.G. (2001). Clastic Facies Models, A Personal Perspective, Bulletin of the Geological Society of Denmark, 48, Copenhagen, 101-115.

Rizal, Yan., Santoso, W. D., Rudyawan, A., Tampubolon, R. A. \& Nurfahan, A. A. (2018a). Sedimentary Facies and Hydrocarbon Reservoir Potentioal of Sand Flat in the Upper part of Tapak Formation in Banyumas Area, Central Java. (2018). Journal Ris. Geo. Tam, 28(2), 251-263 doi: 10.14203/risetgeotam2018.v28.835

Rizal, Yan., Santoso. W. D., Rudyawan, A., Setiaji, R. A. \& Purwasatriya, E. B. (2018b). Turbidite Fasies of Lower Penosogan Formation in Karanggayam Area, Kebumen, Indonesia, Modern Applied Science, 12(6), URL: https://doi.org/10.5539/mas.v12n6p124

Rizal, Yan., Lagona R. \& Santoso W.D. (2017). Turbidite Facies Study of Halang Formation on Pangkalan River, Karang Duren - Dermaji Village, Banyumas District, Central Java-Indonesia, 2nd Transdisciplinary Research on Environmental Problems in Southeast Asia- IOP Conf. Series: Earth and Environmental Science, 7,1 doi :10.1088/1755-1315/71/1/012032

Rizal, Yan, Waluyo G., Irawan, S.A. \& Rudyawan, A. (2016). Facies Study of the Halang Formation Turbidites in Cibalung Area, Cimanggu District, Cilacap Regency, Central Java - Indonesia, Journal of Earth Science \& Climatic Change, 7, 8 doi : 10.4172/2157-7617.1000363

Satyana, A.H. (2007). Central Java, Indonesia-a "Terra Incognita" In Petroleum Exploration: New Consideration on the Tectonic Evolution and Petroleum Implication, Proceeding Indonesia Petroleum Association, $31^{\text {st }}$ Annual Convention.

Shanmugam, G. (1985). Is the Turbidite Facies Association Scheme Valid for Interpreting Ancient Submarine $\begin{array}{lllll}\text { Fan Environments?, Journal } & \text { of }\end{array}$ https://doi.org/10.1130/0091-7613(1985)13<234:ITTFAS >2.0.CO;2

Shanmugam, G. (2006). Deep Water Processes and Facies Models: Implication for Sandstone Petroleum Reservoirs, Elsevier, Netherland.

Stow, D.A.V. (1985). Deep Sea Clastics: Where Are We and Where Are We Going?, Sedimentology: Recent Developments and Applied Aspect, Brechley, P.J. and Williams, B.P.J., Editor, Special Publication Geological Society of London, 18, 67-93. https://doi.org/10.1144/GSL.SP.1985.018.01.05

Tampubolon, R. A. (2014). Geology and Facies Study of Halang and Tapak Formation in Gumilar Area, Banyumas, Central Java Province, Bachelor Thesis, Institut Teknologi Bandung (unpublish).

Tobing, S.M. (2002). Inventarisasi Endapan Bitumen Padat Daerah Wangon dan Sekitarnya, Kabupaten Banyuman dan Kabupaten Cilacap, Provinsi Jawa Tengah, Direktorat Inventarisasi Sumber Daya Mineral, Bandung.

Van Bemmelen, R.W. (1949). The Geology of Indonesia, Martinus Nijhof, The Hague, The Netherland.

\section{Copyrights}

Copyright for this article is retained by the author(s), with first publication rights granted to the journal.

This is an open-access article distributed under the terms and conditions of the Creative Commons Attribution license (http://creativecommons.org/licenses/by/4.0/). 